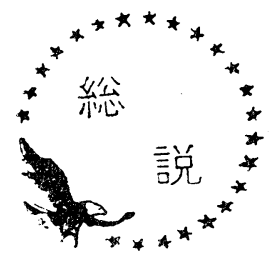

\section{I 、研究の経緯}

この研究は当初からこのような長期にわたる継続的 研究となることを予想して着手されたものではない。 はじめの予定では恐らくカ 1 月足らずで片付く筈だつ え社内のある照合試験の結果が全く予想に反し，意外 なデータが得られたことがこの研究の端緒となつた。

昭和 27 年 9 月, 著者の所属する昭和石油株式会社の 社内の試験研究室（当時全国で 8 力所）で常用されて いた工業粘度計合計19台に対して, 補正のための照合 試験が行なわれた。当時はまだ現在のよらな J I S 規 格が制定されていなかつたため（現行規格の制定は昭 和31年), 各種石油製品の粘度測定にはレッドゥッド I 号型粘度計やセイボルト・ユニバーサル粘度計など のいわ河る業粘度計が広く用いられていた。

この種の粘度計は, それぞれ基準計器の寸法に合せ て製作されてはいるが，篇密には個々の粘度計によつ て多少のカタヨリがあり，それぞれ固有の器差を示 す。

この照合試験においては, 粘度の異なる12種類の試 料油が各試験室に配付され，各所で一せいに粘度の測 定が行なわれた。そのデータが集計され，推計学的方 法によつて解析された結果, レッドゥッド粘度計の場 合には，予想に反した意外な事実が認められた。すな わち, この粘度計の場合には, 補正係数が粘度とと むに系統的に変化するという異常な傾向が認められ た ${ }^{1)}$ 。その結果, 個々の粘度計の補正係数を決定する ことは不可能となつた。他方, セイボルト粘度計の場 合にはそのような特異な傾向はなく，粘度の大小には 無関係に補正係数は一定となり，予定どおり，各粘度 計にそれぞれ固有の補正係数を決定することができ た。

レッドウッド粘度計の場合のこのような異常なデー タの得られた原因について検討した結果, 結局この照 合試験の基準として用いたウベローデ粘度換算表に系 統的な誤りの含まれていることが予想された。そこ
で，この換算表の基礎となつている研究について調查 するとともに，レッドウッド秒と動粘度との換算関係 を明確にする目的で新たに実験を計画した。

結果の普遍性と正確さを期すため,レッドウッド秒 の実測には英国製でN P L（英国の国立物理学研究所 であり,レッドウッド粘度計の基準計器の保管されて いる所）で補正された 4 台のレッドウッド I 号型粘度 計を用いた。また動粘度はマスター粘度計を用い，20 ${ }^{\circ} \mathrm{C}$ の水の粘度を基準にして, 害測した。 $30^{\circ} \mathrm{C} \sim 100^{\circ} \mathrm{C}$ の温度範囲で約 $2 \sim 200 \mathrm{cSt}$ の粘度範囲の鉱油 27 種類 により粘度の比較測定を行ない，その実験データにつ いて種々検討した結果, 実験式として適当と思われる 次式を見出した ${ }^{233)}$ 。

$$
t_{R}=\nu / K\left(1-10^{-\alpha \nu^{\beta}}\right)
$$

ここに $t_{R}:$ レッドウッド秒 $(\mathrm{sec})$, レ : 動粘度 $(\mathrm{cSt})$

$K, \alpha, \beta:$ いずれも常数。

そこで, この式の常数 $K, \alpha, \beta$ の值を最終的に決 定するに当り著者らの実測值だけでなく, 多くの他の 研究者たちによる実測值をも総合して検討した。この ようにして最終的な実験式を誘導し, その式から新換 算表を作成した ${ }^{233)}$ 。そして, 従来の表の不備な点を明 確にした。

他方, 動粘度からセイボルト・ユニバーサル秒への 換算に広く用いられているASTM の粘度換算表は 1937年 ASTM 粘度専門委員会の Headington $ら^{4)}$ に よつて，多くの実験データから図的に求为られたもの であり, 実験式はない。これは, 多くの研究者たちの 努力にもかかわらず適確な実験式が見出されなかつた ために，止むをえずとられた手段のようである。そこ で著者は, この Headington らのデータと著者らのデ 一タとを総合的に検討した結果，(1) 式と全く同型の 実験式が動粘度からセイボルト・ユニバーサル秒への 換算にも適確であることを認めた ${ }^{576) 。 ~}$

さて, 先述の粘度換算式を見出すために行なつた害 験において, 著者が用いたマスター粘度計はＩＰの粘 
度委員会が1952年に発表した懸垂液面（S L）型のも のであつた。この粘度計による実測值の精度と正確度 について種々検討した結果, この構造では粘度測定の 誤差を標準偏差で表わして $0.1 \%$ (繰り返し性になお すと約 $0.3 \%$ ) 程度に保つことが限度と思われ，0.03 $\%$ （繰り返し性で約 $0.1 \%$ ) 程度を望むことは困難と 思われた。そこで種々の型のマスター粘度計を設計し 実験を行なつて検討した結果, 最終的には標準偏差で およそ $0.02 \sim 0.03 \%$ で精密測定のできるマスター粘 度計を得た ${ }^{2(3) 7) ~ 12) 。 ~}$

さて, 上述の工業粘度計, マスタ一粘度計, および 一般のウベローデ型あるいはキャノン・フェンスケ型 粘度計は, 測定原理からすれば, いずれも毛細管型粘 度計に属する。この種の粘度計による粘度測定の原理 として現在広く用いられているのは, Hagenbach と Couette によつて修正された Hagen-Poiseuille の式13) である。

しかしながら, 近年, この式が豲密には実験事実を 表わさないことが認められている。著者む, 自己の上 述の種々の実験データについて検討したところ, やは 少実験事実を適確には表わさない事実を認めた。そこ で種々検討した結果, Poiseuille の上式の代りに (1) 式と全く同型の式を用いるときわめてよく実験事実を 表わすことを確認した。しかも(1) 式によつて運動エ ネルギー補正を行なうことができ, 従来不明確であつ た運動エネルギー補正係数 $m$ とレイノルズ数 $R_{e}$ と の関係をも明確にすることができた ${ }^{9) 11(14) \sim 17) 。 ~}$

さらに, この $m$ と $R e$ との関係から推算して, 現 在 (1953年以来) 国際的な粘度の基準として用いられ ている $20^{\circ} \mathrm{C}$ の水の絶対粘度の值 (米国 NBS の Swindells ら ${ }^{17)}$ の実測值を基礎とした值）がおよそ0.1 $0.2 \%$ 過小纪算出されている疑いのあることが推定さ れた ${ }^{918) 。 ~}$

さらにまた, 従来もつぱら輸入して用いられてきた 粘度標準液の国産化を目的とし, 著者らは工業技術院 計量研究所と同資源技術試験所と協同研究を行なつて きた。その結果, 10 種類の標準液の製造法を確立し ${ }^{103}$ 4992021161), 昭和35年 8 月から市場に供している。

また，著者らはこの10年間, ガラス製毛細管型粘度 計について, ほぼ定期的に校正実験を行なってきた が, その結果, この種の硬質ガラス製粘度計は一般に 経時変化があり, その粘度計定数は年々減少する傾向 にあることを認めた 62 。

このような研究の内容につマて, 以下詳しくのべた w。

\section{II . 工業標準規格としての石油類の粘度測定法}

一般に, 液体の粘度を測定する方法を測定原理から 大別するとつぎの 6 種類が考えられる ${ }^{22)}$ 。(1) 毛細管 の中を流れる試料液体の流速を測定する方法。(2) 試 料液体の中を移動する物体の速度を測定する方法。 （3）試料液体の中で物体を回転させ，その回転速度ま たは回転のトルクを測定する方法。(4) 運動中の他の 物体から試料液体を介して伝達される力より生ずる物 体の歪を測定する方法。(5) 試料液体の中で振動して いる物体の減衰速度を測定する方法。(6) 試料が圧縮 されたとき示す歪を測定する方法である。

このうち, 石油類の粘度測定法として古来最もなじ みの深いのは (1)の方法であり, 毛細管法と称されて いる。それにつぐのは (2)の方法に属する落体法であ る。

石油類を対象とする粘度測定法のうちで，現在の工 業標準規格の中に標準法として規定されているものを 第 1 表にあげた。ただしここには，わが国および米英 独のもののみを示した。

この第1表から明らかなよらに，ASTM D 445 と IP 71 の動粘度試験方法はともにごく最近に, 標準法 として採用されたものである。しかしながら，暫定的 な試験方法としては，すでに1935年頃から採用され， 広く実用されてきた方法である。また，レッドウッ ド, セイボルト, エングラーなどの工業粘度計は第 1 表のように 1924 1932 年頃に工業標準法として採用 されたものである。しかしながら，実際にはいずれも 1885年頃から，すでに石油工業で実用されていた ${ }^{13)}$ 。

わが国では, これらの工業粘度計は戦前に海軍 ${ }^{23)}$

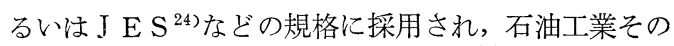
他で広く用いられてきた。しかしながら，戦後にいた り,これらの粘度計はその基準が不明確であること， 測定值が厳密には粘度を表わさない場合があることな ぞの理由で, 新しいJ I S 規格からは除外された。そ して最近では, 石油類ではアスファルト乳剂の粘度測

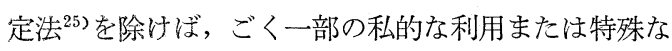
研究目的に限つて使用されるにいたつた。そして, そ の代りに, ウベローデ型, キャノン・フェンスケ型な どのガラス製毛細管粘度計による測定法が採用されて いる。

このように,わが国の石油工業では動粘度を実測 し, 必要に応じて粘度換算表により, レッドゥッド 秒，セイボルト秒に換算する方法が規定されている。 また，第 1 表から明らかなように，米英独各国におい てもガラス製毛細管粘度計による方法が標準法として 


\section{第 1 表 工業標準法としての石油類の粘度測定方法}

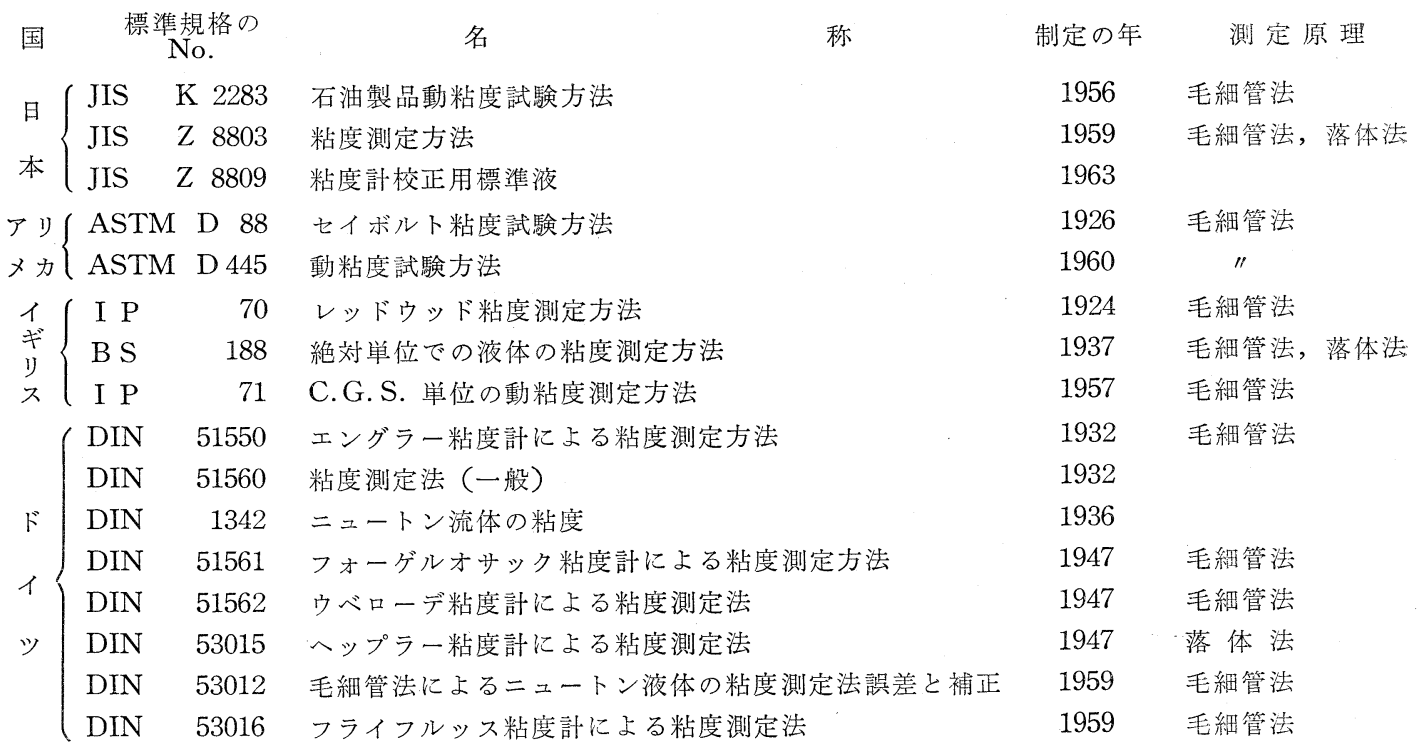

採用され，工業粘度計とともに主要な方法として普及 しつつある。

なお一部では，落体法による粘度測定法が工業禋準 法として採用されてはいるが，石油工業では，毛細管 法に較べるとまだそれ程普及しているとも思われな w。

\section{III. 粘度の換算}

動粘度からレッドウッドI 号秒への換算について， 初めて実験を行ない実験式を発表したのは Higgins ${ }^{26)}$ （1913)である。すなわち，次式のとおりである。

$$
\nu=A t_{R}-B / t_{R}
$$

ここに, $:$ 動粘度 $(\mathrm{cSt}), t_{R}$ : レッドウッド I 号秒 (sec), $A, B:$ 常数。

その後, 多くの研究が行なわれたが，(2) 式は不満 足であるとして，1936年，I Pの粘度委員会のもとで Barr ${ }^{27) ， G a r n e r}{ }^{28)}$ らによつて実験が行なわれ，この 両実験結果から最終的に次式が得られた。

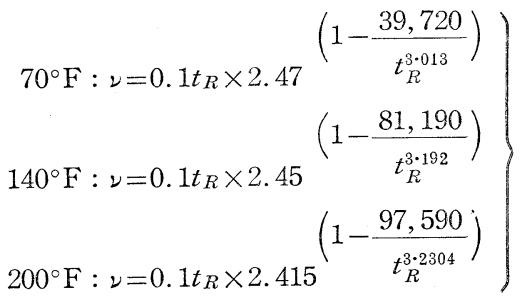

I Pではこの (3) 式を採用し， $70,140,200^{\circ} \mathrm{F}$ の粘 度換算表 ${ }^{29}$ を作成した。これが現在のＩＰ換算表の

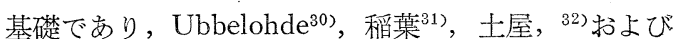
JIS-K 2283 付表などの換算表の基礎となつている。

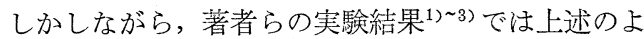
うに，上記の各換算表には系統的な特異な誤差の含ま

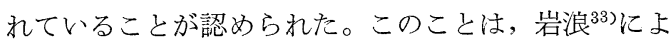
り流体力学的研究結果からも確認された。すなわち, 動粘度 レ(cSt) の液体をレッドウッド I 号型粘度計に よつて注意深く実測した值を $t_{R}(\mathrm{sec})$ とし，他方上 記いずれかの換算表によつてンを換算し $t_{R} 0(\mathrm{sec})$ を 得た場合，次式からその粘度計の相対偏倚 $\delta(\%)$ を 算出する

$$
\delta=100\left(t_{R}-t_{R O}\right) / t_{R O}-\delta_{0}
$$

ここに $\delta_{0}$ : 各粘度計に固有のカタヨリを表わす。

このような $\delta$ をいらろのンについて実測し, レ に対してプロットすると第 1 図のよらになる233)この 図は上述の従来の換算表に含まれている共通な系統的 誤差を示している。

このような換算表の代りに正確な新しい換算表を得 る目的で, 著者は自己の実験結果ならびに従来文献上 に報告されている上述の Barr, Garner らなどの実験 データについて総合的に検討した結果, 先述の式 (1) のような実験式が適確であることを認めた年 ${ }^{23)}$ 。

(1) 式はつぎのように書きかえられる。

$\log \log \left\{K /\left(K-\nu / t_{R}\right)\right\}=\log \alpha+\beta \log \nu$

この式から明らかなように，(1) 式が適確かどうか は, 実験值加ら (5) 式の左辺 $\log \log \left\{K /\left(K-\nu / t_{R}\right)\right\}$ 
を算出し，これを $\log$ レ対してプロット すれば直線が得られるかどらかによつて判 定できる。上述の文献值ならびに著者の実 験データについてプロットした結果は第 2 図のと抢りであつた。これらの結果から， 総合的に(5) 式の $\alpha, \beta$ の值を算出し, ま た $K$ と温度との関倸をも究明した結果, 最終的には次式を得た ${ }^{233)}$ 。

$$
\begin{array}{r}
t_{R}=(4.048+0.00062 \theta) \nu / \\
\left(1-10^{-0.06668 \nu^{0.9704}}\right)
\end{array}
$$

ここに $\theta:$ 温度 $\left({ }^{\circ} \mathrm{C}\right)$ 。

そこで，この (6)式を用、第 1 図のデータ

について検討した結果は，第3図のと预り

となつた。第 3 図から明らかなように，(2) 式のよう な系統的な誤差は認められない。しかも(6)式は $70^{\circ}$ F において $70 \mathrm{cSt}$ 以上の粘度範囲ではレッドウッド 粘度計の基準計器の值に一致して I Pの規格の基準を 満足し, かつ通常のレッドウッド粘度計による実験值 だけでなく, 岩浪らの流体力学的研究結果からの計算 值に対してもよく当てはまる。そこで著者は (6) 式か ら，20 100 ${ }^{\circ} \mathrm{C}$ の範囲の種々な温度について新換算表

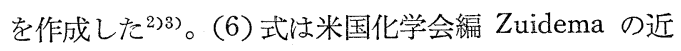
著 ${ }^{34}$ にも引用されている。

つぎに, 動粘度からセイボルト・ニニバーサル秒へ の換算については, Herschel ${ }^{35)}$ (1919) 以来多くの研 究があり，(2) 式と同型の式が用いられていた。しか しながら，その式を用いると， $100 \mathrm{sec}$ を境にして少 くとも 2 つ式が必要であると結論されていた。また 適確な実験式は見出されなかつた。このために, ASTM 粘度専門委員会の Headington らは実験を行 ない，多くの実測值をグラフ上にプロット し，それらを結ぶスムースな曲線を描き， この曲線から, 動粘度とセイボルト秒との 換算表を作成した ${ }^{4)}$ ここが現在の ASTM ${ }^{36)}$ および JIS-K 2283 付表の換算表の基礎 となつている。

そこで著者は, 自己の実験データだけで なく，上記の Headington らの実測値をも 総合して検討した結果, 先述の (6) 式と全 く同型の次式がきわめて適確な実験式であ ることを認めた。

$$
\begin{aligned}
t_{S}= & (4.6050+0.000297 \theta) \nu / \\
& \left(1-10^{-0.07445^{0.9538}}\right)
\end{aligned}
$$

ここに $t_{S}:$ セイボルト・ユニバーサル秒 $(\mathrm{sec}), \theta:$ 温度 $\left({ }^{\circ} \mathrm{F}\right)$ 。

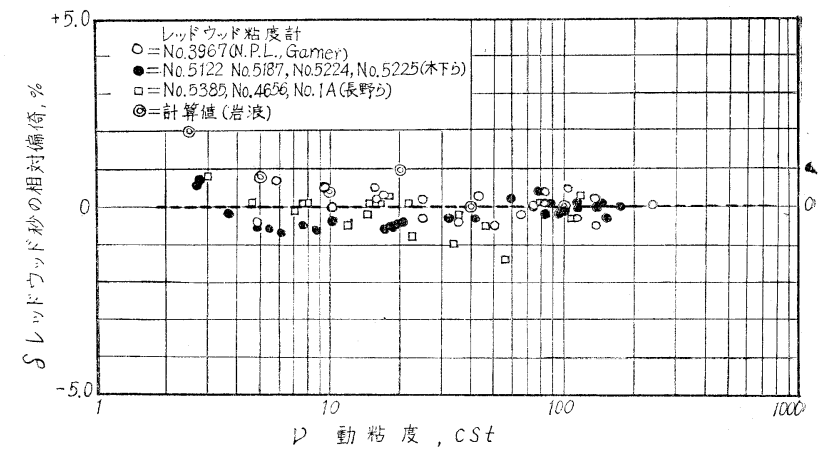

第 3 図 著者の実験式を用いた場合のレッド ウッド秒の相対偏倚 $\delta$ と動粘度 2 との関係 ${ }^{233}$ 
この（7）式から算出されるセイボルト秒は，70３00 ${ }^{\circ} \mathrm{F}$ の温度範囲で $2 \mathrm{cSt}$ 以上の粘度の全域にわたつて, Headington らの実験值掞よび ASTM 換算表から 0.23\%（標準偏差で）偏倚するにすぎないことを確認 した。この偏倚はセイボルト粘度計による実験誤差範 囲内の值である。

さらにまた，著者は動粘度とエングラー度との換算 について検討した結果, レッドゥッド秒, セイボルト 秒の場合と同様に (1) 式がよく当てはまることを認め た。

\section{IV．毛細管粘度計の運動エネルギー補正}

石油類の粘度測定には，現在主に毛細管法が用いら れていることはすでにのべた。毛細管法によつて粘度 を測定する場合の理論式として用いられているのは， Hagenbach-Couette によつて修正された次の HagenPoiseuille の式である。

$$
\gamma=\frac{\pi r^{4} P t}{8 V(l+n r)}-\frac{m \rho V}{8 \pi(l+n r) t}
$$

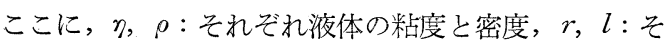
れぞれ毛細管の半径と長さ， $P$ : 毛細管の両端におけ る圧力差, $V$ : 時間 $t$ の間に毛細管内を流れる液体の 容積, $m, n$ : 常数。とくに, $m$ は Hagenbach 係数 または運動エネルギー補正係数といわれ， $n$ は端末効 果についての Couette の補正係数と呼ばれている。右 辺第 2 項は運動エネルギー補正項と呼ばれている ${ }^{13)}$ 。

先述の工業標準法に採用されているキャノン・フェ ンスケ型, ウベローデ型など自然流下型の毛細管型粘 度計においては

$$
P=\rho g h
$$

ここに $g$ : 重力加速度, $h$ : 平均有効液柱の高さ, で あるから(8)式はつぎのようになる。

$$
\nu=\frac{\eta}{\rho}=\frac{\pi r^{4} g h t}{8 V(l+n r)}-\frac{m V}{8 \pi(l+n r) t}
$$

さて, この $m, n$ の值については古くから理論的に も実験的にも多くの研究があるが, 意見の一致に欠け るところである。従来の研究の結果を総括すると, $m$, $n$ の值はいずれもおよそ $0 \sim 1.5$ 程度の範囲にあると いわれてきた ${ }^{13)}$ 。また， $m$ は毛細管内の流れの速さし たがってレイノルズ数 Re の大小とは無関係に一定で あると考えられてきた ${ }^{13) 17) 。 ~}$

さて, 粘度計が与えられれば, その構造寸法が与え られ，(8)，(10）式はそれぞれつぎのように書き換え られる。

$$
\eta=C P t-B \rho / t
$$

および

$$
\nu=K t-B / t
$$

ここに, $C=\pi r^{4} / 8 V(l+n r), \quad K=g h C, \quad B=m V / 8 \pi$ $(l+n r), C, K$ はともに粘度計定数, $B$ は粘度計係 数と呼ばれている。

さらに，この両式はつぎのように書き換えられる。

$$
\begin{aligned}
& P t=\eta / C+B \rho / C t \\
& \nu / t=K-B / t^{2}
\end{aligned}
$$

まず (13) 式の場合には， $\eta ， \rho$ 既知の液体を用い，圧 力 $P$ をいろいろと変化させ流下時間 $\mathrm{t}$ を実測し, そ の結果から Ptを $1 / t$ に対してプロットすれば一つの 直線が得られる。(なお, この場合, 横軸を $1 / t$ の代 りにレイノルズ数 $R e(=2 \mathrm{~V} / \pi r \nu t)$ としても, 直線が 得られる)。この直線と繸軸との交点は, $\eta / C$, この 直線の勾配は $B \rho / C$ であるから, この直線からこの 粘度計の定数 $C$ と $B$ の值を求めることができる。 これが, Bingham 型のように圧力 $P$ をいろいろ変え ることのできる粘度計に対して従来用いられてきた校 正方法であり，かつ運動エネルギー補正の方法でもあ つた。

しかしながら，実験の結果では，上述のような直線 はえられず，厳密には第 4 図のような特徵のある曲線 となることが認められている911118337)。この曲線の特 徴はレイノルズ数 $R e$ が小さい範囲では Pt は一定で あるが，ある $R e$ 以上になると $P t$ は次第に大きくな り，る $R e$ のかなり広い範囲では $P t$ と $R e$ とは 直線関係を示し,さらに $R e$ の大きい範囲では $P t$ は 次第に直線からはずれて S字形を示し，つマに乱流に 移行していく。

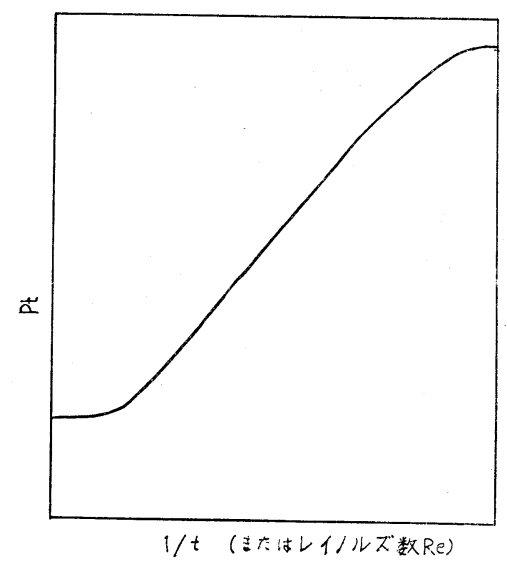

第 4 図 実験結果から得られるPt と $1 / \boldsymbol{t}$ の関係 ${ }^{11}$ 
このよらな事実に詨して, Swindells ら ${ }^{37)}$ は実験デ 一タをグラフ上にプロットし，それらの点を結ぶスム 一スな曲線を描き，この曲線を用いて粘度計の校正を 行なつている。著者らの研究の結果では, さきにレッ ドウッド粘度への換算式として見出した（1）式と全 く同型の次式が，第 4 図の曲線をほとんど完全に表わ すことができ，運動エネルギー補正を精確に行なえる ことを認めた ${ }^{15)}$ 。

$$
\eta=C P t\left\{1-10^{\left.-\alpha^{\prime}(\eta) P\right)^{\beta^{\prime}}}\right\}
$$

ここに, $\alpha^{\prime}, \beta^{\prime}:$ 実験常数。

つぎに (14) 式の場合には, 動粘度ンのわかつた液 体 2 種類以上を用い, その流下時間 $t$ を実測し, $\nu / t$ ： を $1 / t^{2}$ に対してプロットすれば直線が得られる。(こ の場合 $1 / t^{2}$ の代りにレイノルズ数 $R e$ を横軸にとつ ても同様である。）この直線と縦軸との交点は $K$, そ の勾配は $B$ である。このようにして $K, B$ の值を求 める方法が, 先述のウベローデ型, キャノン・フェン スケ型など一般の粘度計に対して従来用いられてきた 校正の方法であり, 運動エネルギー補正の方法でもあ る。

しかしながら，この場合も実験の結果では，上述の ような直線は得られず，焂密には曲線となることぶ近 年になつて認められている11)14)16)38>39>40)41)。一例を第 5 図に示す。すなわち, (14)式は厳密には実験事実を 表わさないことが認められている。このために，つぎ のよらな実験式が最近提案された。

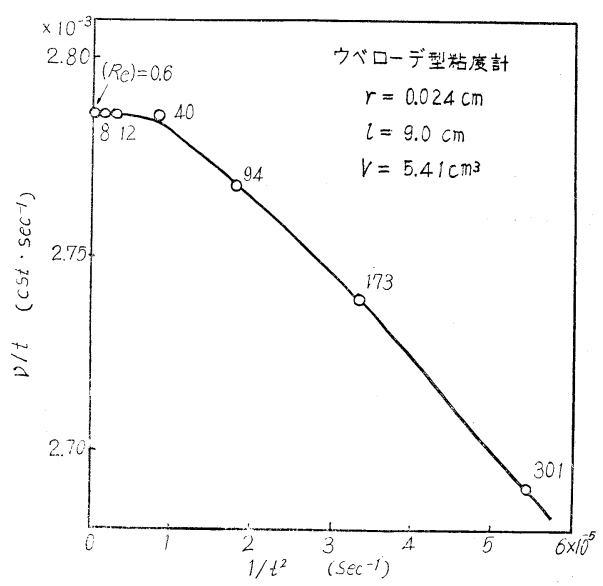

第 5図 ウベローデ型粘度計によつて実測さ れた $\nu / t$ と $1 / \boldsymbol{t}^{2}$ との関係 ${ }^{14)}$
Cannon らの式 ${ }^{40)}$ :

$$
\nu=K t-E / t^{2}
$$

Caw-Wylie の式 ${ }^{41)}$ :

$$
\nu=K t-F / t^{4}
$$

ここに, $E, F:$ ともに実験常数。

著者は, 自己の実験データに基ずいて検討した結 果, この場合にも，先に著者が見出した実験式 (1) 式 と同型の次式が実験事実を適確に表わすことを認め た。

$$
\nu=K t\left(1-10^{-\alpha \nu}{ }^{\beta}\right)
$$

ここに， $\alpha, \beta:$ 実験常数。

このように (11)，(12）式が厳密には実験事実を表 わさない原因としては, 運動エネルギー補正係数 $m$ が一定でなく, レイノルズ数 $R e$ とともに変化するた めであると考えられる。Cannon ら ${ }^{40)}$ はその実験結果 から次式を報告している。

$$
m=0.037(\operatorname{Re})^{0.5}
$$

著者は，上述のように（15)，(18）式が実験事実を 適確に表わす事実から，(8)，(10）式とこれらから次 式を導いた。

$$
\begin{aligned}
& m=8 \pi(l+n r)\left(C P t^{2}-\eta t\right) / \rho V \\
& m=8 \pi(l+n r)\left(K t^{2}-\nu t\right) / V
\end{aligned}
$$

この式を用い，自身の実験データについてだけでな く, Poiseuille ${ }^{42)}$, Rieman ${ }^{43)}$, および Swindellsら ${ }^{37)}$ の実験值について検討し， $m$ と Re の関係について 多くの知見をえた。

Poiseuille のデータから算出した $m$ と Re との関 係を一例として第 6 図に示した。 $m$ の值は従来いわれ ているような一定值ではなく，Re とともに変化する。 毛細管あるいは粘度計によつて柏違はあるが，一般に $R e$ がおよそ 10 以下では $m=0,10$ 以上の範囲では, $m$ は $R e$ とともに次第に増加し, およそ 100 1, 000 の範囲で最高值に達し, それ以上の $R e$ の範囲では $m$ はかえつて減少し, ついに乱流に移向していく。この ような $m-R e$ の関係は上述のように粘度計ごとに多 少異なるが，これは毛細管の両端の形状および毛細管 断面の真円度などによるものであり，実験の結果 ${ }^{16)}$ 第 7 図に示した。

なお，(20)式から明らかなよらに， $m$ の算出には Couette の補正係数 $n$ の值が必要である。しかしな がら, 先述のよらに $n=0 \sim 1.5$ 程度の值では, 第 6 図, 第 7 図の場合， $m$ の值への影響は $1 \%$ 程度以下であ り，事実上無視できる。

さて,このような $m$ の特性が明らかになると, 多くの 再検討すべき問題が生じてくる。そのうち最も重要と 


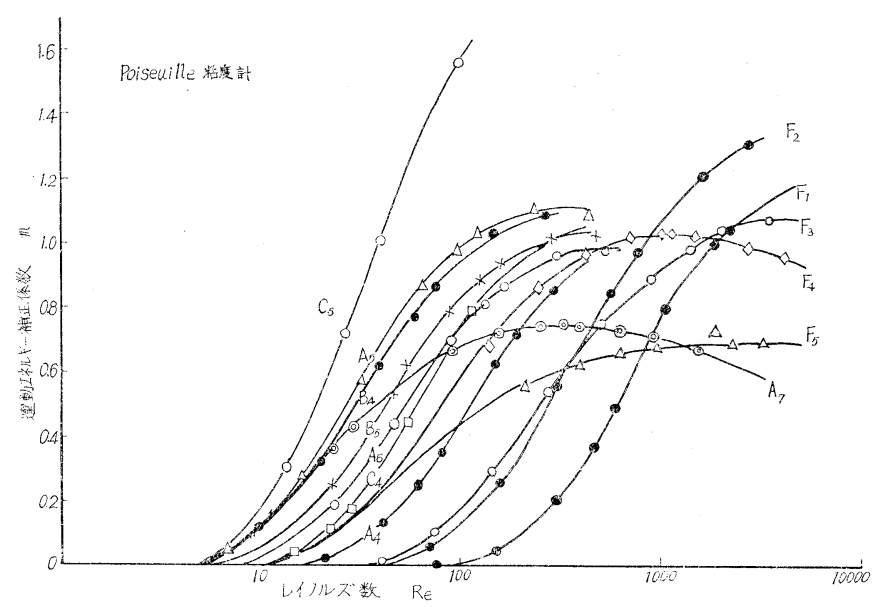

第 6 図 Poiseuille の実測值から算出したと $\boldsymbol{m}$ と $\operatorname{Re}$ の関係 ${ }^{11118)}$

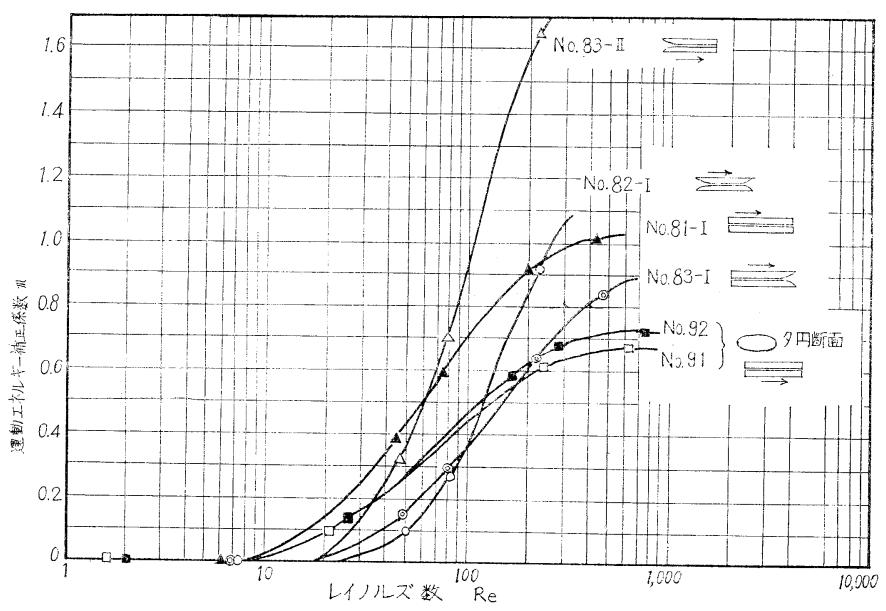

第 7 図 運動エネルギー補正係数 $\boldsymbol{m}$ とレイノルズ数 $R e$ との関係におよぼす毛細管の形状の影響 ${ }^{16)}$

思われるのは, $20^{\circ} \mathrm{C}$ 水の絶対粘度の值である。現 在，国際的な粘度の基淮として用いられている 1.002 $\mathrm{cP}$ は, 米国 NBS の Swindells ら ${ }^{17}$ によつて20年余 の年月にわたつて精密に絶刘測定された值 $1.0019 \pm$ $0.0003 \mathrm{cP}$ にもとずいている。しかも，その絶対測定 の基礎的な前提として運動エネルギー補正係数 $m$ は レイノルズ数にかかわらず一定であるとして (8) 式が 用いられた。そこで, 著者は上述のような $m-R e$ の 関係を考慮し，(15）式を用いて Swindells らのデー 夕を解析した結果, 上述の $20^{\circ} \mathrm{C}$ の水の絶対粘度の值 $1.0019 \mathrm{cP}$ はおよそ $0.1 \%$ 過小に算出されていること が推定された ${ }^{8) 9111 \%}$ 。

$20^{\circ} \mathrm{C}$ の水の絶対粘度の值については, その後,
Peter ら ${ }^{44)}$ および Roscoe ら ${ }^{45)}$ によつて毛細管法以外 の方法で絶対測定され，それぞれつぎのような值が報 告されている。

Peter ら : $\eta=1.003 \pm 0.002 \mathrm{cP}$

Roscoe $ら: \eta=1.0025 \pm 0.0005 \mathrm{cP}$

著者の推定では, $20^{\circ} \mathrm{C}$ 水の絶対粘度の真の值は, お そらく $1.003 \mathrm{cP}$ 近くに輁り, 現在広く用いられてい る上述の值はいずれ再検討されるものと考えている。 な㧍, $20^{\circ} \mathrm{C}$ の水の粘度のように $1 \mathrm{cP}$ 程度の液体の粘 度を毛細管法によって正確に絶対測定する場合には, 事実上 $m$ が 0 となる範囲すなわち，およそ10以下の レイノルズ数の範囲で実験の行なわれることが望まし い。 


\section{$\mathrm{V}$. 粘度禋準液とマスター粘度計}

先述の Bingham 型粘度計のように, 圧力 $P$ をい ろいろ変えて $t$ 定実測するタイプの毛細管粘度計にお

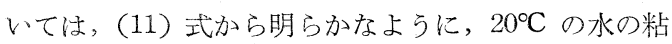
度といら唯一の基準によつて粘度計を校正することが できる。しかしながら，一般に用いられているキャノ ン・フェンスケ型, ウベローデ型粘度計の場合には (12)式から明らかなよらに，2 種類以上の粘度既知の 液体が必要である。このために, 粘度計校正用標準液 （いわゆる粘度標準液）またはマスタ一粘度計が用い られている。第1表の IP, DIN, BS 法ではマスター
粘度計が用いられ，ASTM，JIS Z では，標準液が用 いられ，JIS K ではこの両者を用いる方法が規定され ている。

マスター粘度計は, Umstätter (1931) ${ }^{46) \sim 48)}$ によつ てはじめて考案されたもので，毛細管の長さがおよそ $40 \sim 60 \mathrm{~cm}$ 程度も市り，(10)式の右辺第 2 項が無視で きるように設計されたガラス製毛細管粘度計である。 マスター粘度計の構造については多くの研究 ${ }^{49) ~ 56) ~ か ゙ ~}$ ある。著者らは第 8 図のよらな種々の構造のマスター 粘度計について, 粘度の測定実験を行なつて検討した 結果，およそ $0.02 \sim 0.03 \%$ 程度の䛊差（標準偏差）

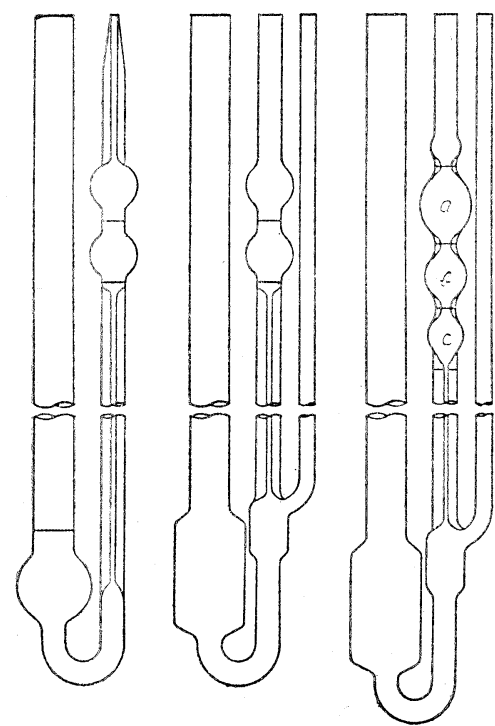

No.1 IP/U(1052)型 N0.2IP/SL(1952)型 N0.3 Umstatter型

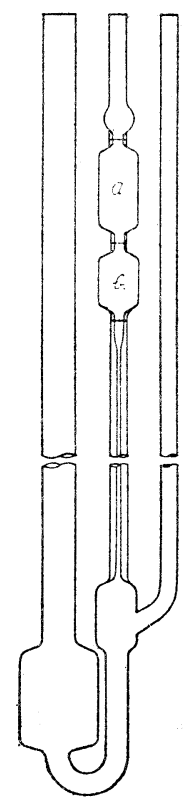

N0.4 SL-20望

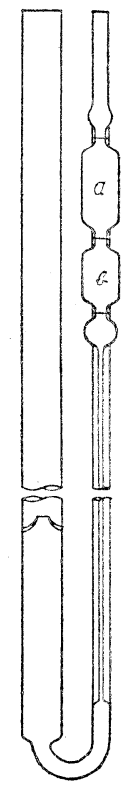

N0.5 U-20型

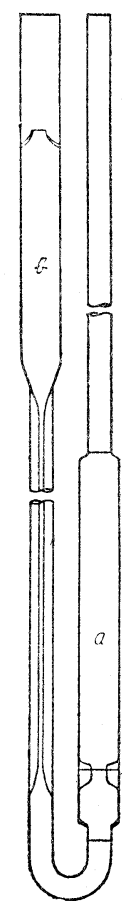

N0.6 湴僦型

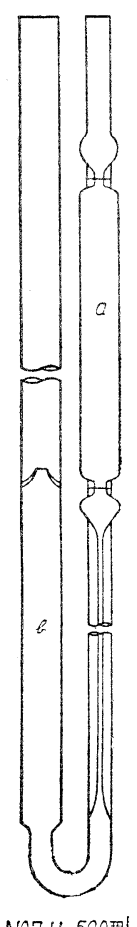

N0.7 U-590型

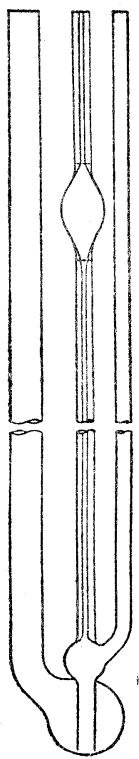

NOS IP/MSLL型

\section{第 8 図マスター 粘度計 ${ }^{10)}$}

で測定できる構造のマスター粘度計をえた 2)3)9110) 12)。 毛細管の内径を異にする数本のマスター粘度計を用い れば，およそ かなり正確な粘度測定が可能である。

粘度標準液は，その粘度が，マスタ一粘度計または 先述の Bingham 型粘度計によつて, 正確に比較測定 された二次的な標準の液体である。従来市販されてい るものとしては NBS, ASTM の粘度標準液がある。 わが国では従来これらが輸入されて用いられてきた。 そこで, 著者らはその国産化を目的とし, 工業技術院
計量研究所および同資源技術試験所と協同研究を行な つてきた。その結果第 2 表のような 10 種類の粘度標準 液の製造法を確立し, 先述のように昭和 35 年 8 月以来 一般に供してきた。これらの標準液は1961年から JIS $\mathrm{K}$ 規格に採用され, また1964年 2 月からは JIS Z 規 格として施行されている。

さて，これら標準液はいずれも石油系炭化水素油で あり, その物理的化学的性質は恒久不変のものではな い。むしろ長期間保存中には变質による粘度変化が起 る。NBS で最近行なわれた実験の結果によれば，低 
第 2 表 著者らが調製した粘度計校正用標準液の概略の粘度 ${ }^{10) 12)}$

\begin{tabular}{|c|c|c|c|c|c|c|c|c|c|}
\hline \multirow{2}{*}{ 標 準 } & \multirow{2}{*}{ 案 液 } & \multicolumn{2}{|c|}{ 動 } & \multicolumn{2}{|c|}{ 度 (cSt) } & \multicolumn{2}{|c|}{ 粘 } & \multicolumn{2}{|c|}{ 度 $(\mathrm{cP})$} \\
\hline & & $20^{\circ} \mathrm{C}$ & $30^{\circ} \mathrm{C}$ & $37.78^{\circ} \mathrm{C}$ & $50^{\circ} \mathrm{C}$ & $20^{\circ} \mathrm{C}$ & $30^{\circ} \mathrm{C}$ & $37.78^{\circ} \mathrm{C}$ & $50^{\circ} \mathrm{C}$ \\
\hline $\mathrm{J} \mathrm{S}$ & 2.5 & 2.5 & 2.1 & 1.8 & 1.5 & 2 & 1.6 & 1.4 & 1.1 \\
\hline $\mathrm{J} \mathrm{S}$ & 5 & 5 & 4 & 3 & 2.5 & 4 & 3 & 2.5 & 2 \\
\hline J S & 10 & 10 & 7 & 6 & 4 & 8 & 6 & 5 & 4 \\
\hline $\mathrm{J} \mathrm{S}$ & 20 & 20 & 14 & 11 & 7 & 17 & 11 & 9 & 6 \\
\hline $\mathrm{J} \mathrm{S}$ & 50 & 50 & 30 & 22 & 14 & 42 & 25 & 19 & 12 \\
\hline J S & 100 & 100 & 60 & 40 & 25 & 85 & 50 & 35 & 20 \\
\hline $\mathrm{J} \mathrm{S}$ & 200 & 200 & 110 & 70 & 40 & 170 & 90 & 60 & 35 \\
\hline $\mathrm{J} \mathrm{S}$ & 500 & 500 & 250 & 150 & 80 & 450 & 220 & 130 & 70 \\
\hline $\mathrm{J} \mathrm{S}$ & 1000 & 1000 & 500 & 290 & 140 & 900 & 440 & 250 & 120 \\
\hline $\mathrm{J} \mathrm{S}$ & 2000 & 2000 & 900 & 500 & 250 & 1800 & 800 & 450 & 200 \\
\hline
\end{tabular}

粘度 $\left(20^{\circ} \mathrm{C}\right.$ で約 $110 \mathrm{cSt}$ 以下) の標準液の場合には, 10 年間の粘度変化は測定の精度 $(0.1 \%)$ 以内であり， 経時変化はとくに認められなかつた。しかしながら高 粘度 $\left(20^{\circ} \mathrm{C}\right.$ で約 $350 \mathrm{cSt}$ 以上) の標準液の場合には 10 年間にわたつてほぼ直線的な粘度增加が認められ，1 年当り $0.1 \sim 0.3 \%$ であつたと報告されている ${ }^{57) 。 ~}$

第 2 表の標準液について，3 年間の経時変化を実測 した結果では JS $200\left(20^{\circ} \mathrm{C}\right.$ で $\left.200 \mathrm{cSt}\right)$ 以下の 7 種類 は粘度測定の精度 $(0.1 \%)$ 以内であり, とくに粘度変 化は認められなかつた。しかしながら， JS $500\left(20^{\circ} \mathrm{C}\right.$ で $500 \mathrm{cSt}$ ）以上の高粘度液の場合に注多少の粘度增 加が認められ，3 年間に最高 $0.3 \%$ 程度が認的られ た。すなわち， 1 年当りの粘度変化は $0.1 \%$ 程度であ つた ${ }^{58) 59)}$ 。

\section{VI． 石油工業での粘度測定の精度}

先述の工業標準法による粘度測定において, ぞの程 度の精度が期待できるかは興味深い。

ASTM の粘度專門委員会は 1959 年，その標準測定 法 D445 を最終的に決定するに先立ち，それるでの暫 定的測定法による精度を実測する目的で, 米国内の代 表的な研究機関13力所の協力で動粘度の照合試験を行 なつた。その結果は第 3 表のとおりであつた。この結 果から, 測定温度と粘度範囲にかかわらず, 動粘度測 定の繰り返し性は $0.35 \%$, 再現性は $0.70 \%$ が適当で あると結論した。そしてこの精度の值が第 1 表の標準 測定法に採用されている。

I Pの粘度専門委員会は1952年 ${ }^{51)}$, 上記と同様の目 的で, 英国内の主要な 11 所の研究機関の参加によつ て動粘度の照合試験を行なつた。その結果注第 4 表の とおりであつた。I Pの粘度測定法は先述のように，

\section{第 3 表 ASTM D445 法による動粘度测定の 精度についての ASTM 粘度専門委 員会の実測値 (1959)}

\begin{tabular}{|c|c|c|c|c|}
\hline $\begin{array}{l}\text { 温度 } \\
\left({ }^{\circ} \mathrm{F}\right)\end{array}$ & $\begin{array}{l}\text { 試料油 } \\
\text { No. }\end{array}$ & $\begin{array}{c}\text { 平均動粘度 } \\
(\mathrm{cSt})\end{array}$ & $\begin{array}{c}\text { 繰り返し性 } \\
(\%)\end{array}$ & 再 $\underset{(\%)}{(\%)}$ \\
\hline \multirow{5}{*}{$100\}$} & 1 & 15.613 & $0.284(12)^{*}$ & $0.499(11)^{*}$ \\
\hline & 2 & 67.010 & $0.228(13)$ & $0.628(12)$ \\
\hline & 3 & 143.686 & $0.229(13)$ & $0.752(12)$ \\
\hline & 4 & 375.216 & $0.401(13)$ & $0.591(12)$ \\
\hline & 5 & 1158.67 & $0.298(12)$ & $0.501(11)$ \\
\hline \multirow{6}{*}{210} & 1 & 3.324 & $0.706(13)$ & $0.631(12)$ \\
\hline & 2 & 8.375 & $0.313(13)$ & $1.01(12)$ \\
\hline & 3 & 13.538 & $0.243(13)$ & $0.577(12)$ \\
\hline & 4 & 24.841 & $0.266(13)$ & $0.606(12)$ \\
\hline & 5 & 28.181 & $0.513(13)$ & $0.666(12)$ \\
\hline & & 平 均 & $0.348(\%)$ & $0.644(\%)$ \\
\hline
\end{tabular}

* 自由度

第4表 IP 71 法による動粘度測定の精度に ついてのIP 粘度専門委員会の案測 值 $(1952)^{51)}$

$$
\begin{aligned}
& \text { ステッ 概略の粘度計の繰り返し性 再 現 性 } \\
& \text { プの数 } \begin{array}{c}
\text { 動粘度 } \\
(\mathrm{cSt})
\end{array} \text { No. （\%) (\%) } \\
& 11 \text { I Pマスター } 0.139(341) * 0.263(375) * \\
& \begin{array}{lllll}
2 & 10 & 0 \text { と } 1 & 0.199(134) & 0.844(154)
\end{array} \\
& \begin{array}{llllll}
3 & 100 & 1 \text { A と } 2 & 0.156(88) & 0.551(97)
\end{array} \\
& \begin{array}{llllll}
4 & 500 & 3 & 0.295(81) & 0.836(89)
\end{array} \\
& \begin{array}{lllll}
5 & 1500 & 4 & 0.577(72) & 1.38(79)
\end{array} \\
& * \text { 自由度 }
\end{aligned}
$$


ASTM と異り，マスター粘度計を用い $20^{\circ} \mathrm{C}$ の水の 粘度の值からステップアップする方法が用いられてい る。したがつてステップが増加するごとに，すなわち 高粘度範囲になるにつれて誤差が累積され, 繰り返し 性はとも角, 再現性は大きい值となる。この実験值が 基礎となつて先述の I P の標準測定法の精度が規定さ れている。

わが国では最近石油学会第 5 部会潤滑油分科会粘度 測定方法専門委員会（著者はその主査）に肪いて，18 力所の試験研究機関の参加により動粘度の照合試験が 行なわれた。 ${ }^{60)}$ その結果は第 5 表のと预りであつた。 その結果, 先述の J I S 法に規定されている繰り返し 性 $0.35 \%$, 再現性 $0.70 \%$ は妥当であり, 工業標準法 の精度としては事実上の限界であると結論された。

\section{第 5 表 JIS K 2283 法による動粘度測定の 精度についての石油学会第 5 部会の 実測值 $(1963)^{60)}$}

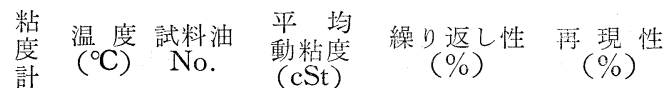

$$
\begin{aligned}
& \text { * }\left(\begin{array}{rrll}
1 & 3.915 & 0.179(18) * & 0.381(17) * \\
2 & 11.858 & 0.092(34) & 0.471(17) \\
3 & 58.197 & 0.072(30) & 0.364(15)
\end{array}\right. \\
& \begin{array}{llllll}
\text { † } & 4 & 268.57 & 0.101(28) & 0.536(14)
\end{array} \\
& \begin{array}{l|lllll}
3 & 5 & 1218.8 & 0.083(15) & 0.624(14)
\end{array}
\end{aligned}
$$

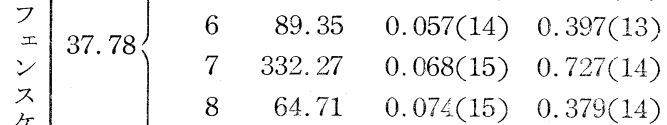

$$
\begin{aligned}
& \begin{array}{l}
\text { 型 } \\
\text { 型 }
\end{array} \quad \begin{array}{rrrr}
8 & 64.71 & 0.074(15) & 0.379(14) \\
9 & 112.55 & 0.104(15) & 0.473(14)
\end{array} \\
& \begin{array}{l|llll}
\text { 抒 } & \\
\text { び }
\end{array} \quad \begin{array}{llll}
10 & 167.25 & 0.140(15) & 0.461(14) \\
11 & 120.94 & 0.107(14) & 0.433(13)
\end{array} \\
& \text { ヴ シ }
\end{aligned}
$$

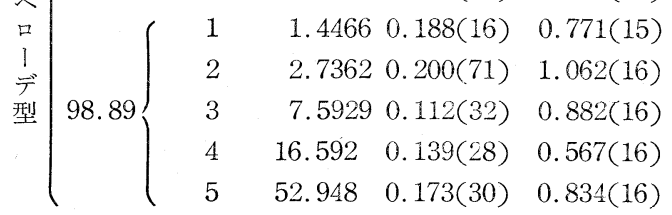

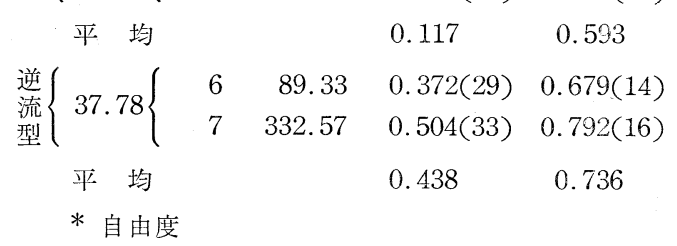

\section{VII. むすび}

以上のように, 著者の行なつた研究のらち, 主なも のについてのべた。この研究によつて著者は石油類の
粘度およびレオロジーについて若干の知見をうること

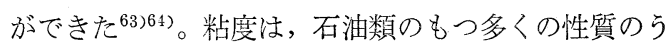
ちできわめて重要な性質の 1 つである。とくに潤滑油 に㧍いては, 粘度は最も重要な性質の1つである。前 項でのべたように，一般に粘度はごく限られた通常の 条件の下で測定されている。しかしながら, 潤滑油な どが実用されている条件は, たとえば, 高温, 低温, 高圧, 高セン断速度, 高レイノルズ数にまでおよんで いる。したがつて，将来はそのような条件の下での石 油類の粘度測定を追究することが，今後の課題である らと考えられる。

\section{文献}

1）木下真清, 燃協誌, 32, No. 318, 569 (1953)

2) 木下真清, 工化, 59, No. 9, 1032 (1956)

3) M. Kinoshita, J. Inst. Petroleum, 43, No.401, 152 (1957)

4) C.E. Headington, J. C. Genisse, Proc. Amer. Soc. Test. Materials, 37, 380 (1937)

5）木下真清, 工化, 59, No.9, 1037 (1956)

6) M. Kinoshita, J. Inst. Petroleum, 43, No, 401, 161 (1957)

7) 木下真清, 小野山益弘, 日化第 8 年会 (1955年 4 月)

8）木下真清, 小野山益弘, 日化第10年会（1957年 4 月)

9) N. Ishii, A. Wakana, M. Kinoshita, The Fifth World Petroleum Congress, V-27 (1959)

10）木下真清, 小野山益弘, 石油誌, 4, No. 9, 23 (1961)

11）木下真清, “粘度測定汇関する研究” (1961)

12）木下真清，小野山益弘，昭石技報， 5 , No.4, 236 (1961)

13) G. Barr, "A Monograph of Viscometry", London (1931)

14）木下真清, 小野山益弘, 工化, 61 , No. 4,428 (1958)

15）木下真清，小野山益弘，潤滑， 3, No. 6, 299 (1958)

16）木下真清, 小野山益弘, 石油誌, 3, No. 2,121 (1960)

17) J. F. Swindells, J. R. Coe, Jr., T. B. Godfrey, J. Research Nat. Bur. Standards, 48, 1 (1952)

18）木下真清, 小野山益弘, 日化第 12 年会 (1959年 4 月) 
19）川田裕郎, 倉瀬公男, 磯崎清, 中央計量検定所報 告, 8, No. 2, 47 (1959)

20）川田裕郎, 磯崎清, 中央計量検定所報告, 10 , No. 2, 1 (1961)

21）木下真清, 小口敏太郎, 小野山益弘, 津田一美, 油化学協会誌, 9, No. 4, 186 (1960)

22) The 54th Annual Meeting, Amer. Soc. Testing Materials (1951)

23) 石油合成法関係試験法, 第10章, 第 1 海軍燃料㪣 (1944)

24) JES No.174 (1932)

25) JIS K 2208-1961.

26) W. F. Higgins, Petroleum World, 10, 268, 324 (1913)

27) G. Barr, J. Inst. Petrolum Technologists, 22, 1 (1936)

28) F. H. Garner, W. E. J. Broom, and J. L. Taylor, ibid., 22, 11 (1936)

29) ibid., 22, 21 (1936)

30) L. Ubbedohde, "Zur Viskosimetrie", Berlin (1940)

31) 永井雄三郎, 稻葉弥之助, “潤滑油の粘度および 粘度温度関係計算用諸表”（1944）

32) 土屋敦彦，潤滑，2，31 (1957)

33）岩浪繁蔵，日本機械学会論文集，108，613 (1955)

34) H. H. Zuidema, "The Performance of Lubricating Oils" Second Ed., Chapt. 2 (1959)

35) W. Hershell, Tech Papers of Bureau of Standards, 16, 210, 238 (1921)

36) ASTM Viscosity Tables for Kinematic Viscosity Conversions and Viscosity Index Calculations (1953)

37) J. F. Swindells, R. C. Hardg, R. C. Cottington, J. Research Nat. Bur. Standards, 52, 105 (1954)

38）川田裕郎, 中央計量検定所報告, 10, No. 2, 1 (1961)

39) 長野隆治, 小熊信, 高分子化学, 14, 397 (1957)

40) M. R. Cannon, R. E. Manning, and J. D. Bell, Anal. Chem., 32, No. 3, 355 (1960)
41) W.A. Caw and R. G. Wylie, British J. Appl. Phys., 12, March, 94 (1960)

42) E. C. Bingham, W. H. Hershel, "Rheological Memoirs" (1940)

43) Rieman III, J.Amer. Chem. Soc., 50, 46 (1928)

44) S. Peter and W. Sliwka, Chemie-Ing.-Techn., 28, 49 (1956)

45) J. Inst. Petroleum, 44, No.419, 394 (1958)

46) H. Umstätter, Z. physik. Chem. 152, 150 (1931)

47) H. Umstätter, Kolloid Z., 102, 239 (1943), ibid., 103, 7 (1943), Dechema Monogr. 14, 72 (1950), Technick 5, 354 (1950)

48) H. Umstätter, Erdöl und Kohle, 7, No. 7, 436 (1954)

49) M. R. Cannon, M. R. Fenske, Oil and Gas J., 33, No. 47, 52 (1935)

50) M. R. Cannon, M. R. Fenske, Ind. Eng. Chem., Anal. Ed., 16, No. 11, 708 (1944)

51) J. Inst. Petroleum, 38, 428 (1952)

52）川田裕郎, 磯崎清, 中央計量検定所報告, 8, No. 2, 56 (1959)

53）川田裕郎，磯㥓清，ibid., 5, No. 3, 61 (1956)

54）川田裕郎, ibid., 5, No. 4, 16 (1956)

55）川田裕郎，伊藤，ibid.，5，No. 2，29 (1956)

56）川田裕郎, 磯崎清, ibid., 6, No. 2, 23 (1957)

57) R. C. Hardy, Nat. Bur. Standards Monograph 55 (1962)

58) 木下真清, 小野山益弘, 計量管理, 12, No. 10, 12 (1963)

59) 木下真清, 小野山益弘, 第 4 回石油学会研究発表 会講演要旨, 52 (1961)

60) 木下真清, 佐藤通男, 山田守, 石油誌, 6, No. 10, 788 (1963)

61）木下真清，小野山益弘，石油誌， 7, No. 1，20 (1964)

62）木下真清，小野山益弘，潤滑，5，No. 4, 237 (1960)

63) 木下真清, 潤滑, 7, No.4, 157 (1962)

64）木下真清, 油化学協会誌, 13, No.2, 63 (1964) 


\title{
Contribution to Viscometry for Petroleum Products
}

\author{
by Masumi Kinoshita \\ (Shinagawa Research Laboratory, Showa Oil Co. Ltd., Tokyo)
}

SYNOPSIS : - An investigation on the viscometry for petroleum products which has been performed by the present author are reviewed in this paper. Especially, the progress of the research work and the main conclusions of the studies are both given. As the result of this investigation, the following conclusions have been drawn:

(1) The Ubbelohde conversion table, which is currently used for the conversion of kinematic viscosities to Redwood No. I seconds, does not represent with certainty the relation obtainable in the commercial Redwood viscometers. The Redwood seconds obtained by conversion from kinematic viscosities by means of the above table show a characteristic deviation from the values observed in the general Redwood insturments at the range of about $2 \sim 30 \mathrm{cSt}$, and the deviation has a maximum amaunting to as much as $3 \%$ at a limited range of about $6 \sim 12 \mathrm{cSt}$.

(2) The following empirical equation, derived by the present author, is suitable for the conversion of kinematic viscosities $\nu$ to Redwood No. I seconds $t_{R}$ in the viscosity range greater than aobut $3 \mathrm{cSt}$ at the temperatures $\theta$ between $20^{\circ} \mathrm{C}$ and $100^{\circ} \mathrm{C}$ approximately:

$$
t_{R}=(4.048+0.00062 \theta) \nu /\left(1-10^{-0.06668 \nu^{0.9704}}\right)
$$

A new conversion table has been developed by the author from this equation to take the place of the Ubbelohde conversion table.

(3) The following empirical equation, which is of the same type as the above equation, is suitable for the conversion of kinematic viscosities 2 to Saybolt Universal viscosities $t_{S}$ in the whole viscosity range greater than about $2 \mathrm{cSt}$ at temperatures $\theta$ between $70^{\circ} \mathrm{F}$ and $300^{\circ} \mathrm{F}$ approximately.

$$
t_{S}=(4.6050+0.000297 \theta) \nu /\left(1-10^{-0.07445 \nu^{0.9538}}\right)
$$

(4) The modified Hagen-Poiseuille equation

$$
\begin{aligned}
& \eta=C P t-B \rho / t \\
& \nu=K t-B / t
\end{aligned}
$$

which are generally used for the capillary viscometry, fail to represent the experimental facts precisely. The following empirical equations, which is of the same type as the equation above derived by the author to express the relation between Redwood seconds and kinematic viscosities, are found to be quite adequate to express the facts.

$$
\begin{aligned}
& \eta=C P t\left\{1-10^{-\alpha^{\prime}\left(\eta^{\prime} P\right)^{\beta^{\prime}}}\right\} \\
& \nu=K t\left(1-10^{-\alpha_{\nu}{ }^{\beta}}\right)
\end{aligned}
$$

where $\alpha, \alpha^{\prime}, \beta$, and $\beta^{\prime}$ are constants.

(5) From these empirical equations and the modified Poiseuille equation, thp relation between kinetic energy coefficient $m$ and Reynolds number $R e$ has been studied, analysing the experimeutal data obtained by other investigators, such as Poiseuille, Rieman, and Swindells et al, as well as by the author. As the result of this study, it was found that 
the coefficient $m$ is not constant but varied with the change of Reynolds number Re. The values of $m$ are practically zero at $R e$ smaller than about 10 . The variation of the curve $m-R e$ is probably owing to the geometric shape of the capillary of the viscometer.

(6) The value of $1,002 \mathrm{cp}$ for the absolute viscosity of water at $20^{\circ} \mathrm{C}$, which is widely used as the primary standard for viscosity determinations were measured by Swindells et al. of the National Bureau of Standard in U. S. A. While their measurement was extremely precise, the calculations were carried out according to the modified Poiseuille equation assuming that $m$ is constant at any Reynolds number. So, it is seems to be necessary to re-examine this valuation. According to the author, the amount of correction is estimated about plus $0.1 \%$.

(7) Magnitudes of errors of various sources in capillary viscometry have been studied experimentally, using eight types of master viscometers such as IP U-tube, IP suspendedlevel type, Umstätter type, and specially designed U-tube type master viscometers. Corrections for kinetic energy, surface tension and drainage etc. are discussed.

On the other hand, viscosity standard liquids have been prepared for calibrating routine viscometers. Viscosities of these standard liquids have been determined at four temperatures from 20 to $50^{\circ} \mathrm{C}$ by means of the "step-up" procedure using master viscometers. The value of $1.0038 \mathrm{cSt}$ kinematic viscosity of water at $20^{\circ} \mathrm{C}$ is used as a primary standard in the viscosity measurements. The experimental errors accumulated in the "step-up" procedure have been estimated by the statistical method.

The results of this study indicate that viscosities of the standard liquids are accurate to such an extent that they are in errors within $0.2 \%$ over a viscosity range from 0.7 to $2,000 \mathrm{cSt}$.

(8) The author who is a chairman of the Viscosity Determination Panel of Japan Petroleum Institute, has carried out an experimental investigation in order to determine the precision of kinematic viscosity determinations using JIS standard method.

In accordance with the programme, twelve selected samples of suitable viscosities covering the range $3 \sim 2,000 \mathrm{cSt}$ were submitted to the eighteen laboratories for kinematic viscosity determination at $37.78^{\circ} \mathrm{C}$ and $98.89^{\circ} \mathrm{C}$. Some sample oils of them contain the various additives such as VI improvers, detergents, and oxidation inhibitions. Statistical analysis were employed to the experimental data reported from the laboratories.

As an approximate summary of this investigation, it may be generalized that the repeatability of viscosity determination by the method is $0.35 \%$, and the reproducibility is $0.70 \%$. 